\title{
Highly Skilled Migrant Women: Achievements and Contributions in Knowledge-Based Economies
}

\author{
Rosa Grimaldi ${ }^{1}$, Francesca Crivellaro ${ }^{2} \mathbb{D}$ and Daniela Bolzani ${ }^{1, *}$ \\ 1 Department of Management, University of Bologna, 40126 Bologna, Italy; rosa.grimaldi@unibo.it \\ 2 Department of Education Studies "G. M. Bertin", University of Bologna, 40126 Bologna, Italy; \\ francesca.crivellar4@unibo.it \\ * Correspondence: daniela.bolzani@unibo.it
}

Citation: Grimaldi, Rosa, Francesca Crivellaro, and Daniela Bolzani. 2022. Highly Skilled Migrant Women: Achievements and Contributions in Knowledge-Based Economies. Administrative Sciences 12: 7. https://doi.org/10.3390/ admsci12010007

Received: 17 March 2021 Accepted: 29 March 2021 Published: 5 January 2022

Publisher's Note: MDPI stays neutral with regard to jurisdictional claims in published maps and institutional affiliations.

Copyright: (C) 2022 by the authors. Licensee MDPI, Basel, Switzerland. This article is an open access article distributed under the terms and conditions of the Creative Commons Attribution (CC BY) license (https:// creativecommons.org/licenses/by/ $4.0 /)$.
Competition among developed industrialised countries for highly skilled migrants has increased in recent decades with the onset of the knowledge-based economy and society (Triandafyllidou and Isaakyan 2014). The share of highly skilled migrants reached 30\% in 2011 (Eurostat 2011), and several Western countries have resorted to migration policies as an instrument to fill the gaps in the supply of skilled workers in knowledge-based economies (European Migration Network 2007; OECD-EU 2016; Burmann et al. 2018).

While highly skilled workers represent key talent pools for companies, they are often the first to lose their jobs in the event of an economic downturn and face poor career outcomes, such as underemployment, brain waste, lower wages, worst working conditions and de-skilling (e.g., Lo et al. 2017), as a result of individual, organizational and environmental factors (Syed 2008; Al Ariss et al. 2012). Despite several governments are taking measures to address inequalities in wages and labour force participation (UNDESA 2020), the anti-immigration sentiment and rampant populism in several countries (e.g., Brexit, US travel ban, and European-level discussions on migration issues) (OECD 2016) does not help in solving discrimination, cross-cultural adjustment and other difficulties (e.g., Dietz et al. 2015).

In addition to these trends, highly skilled migration trends have increasingly feminized over time, both in OECD and non-OECD countries (Özden et al. 2011). Highly skilled female migration presents several peculiar characteristics that are worth noting, such as unconventional migration biographies (e.g., Enríquez and Triandafyllidou 2016); differences in terms of national backgrounds in different host countries (European Migration Network 2007; Kofman 2014); high levels of overqualification and deskilling in the job market with respect to men (Eurostat 2011); and underrepresentation in Science, Technology, Engineering and Mathematics (STEM) sectors (e.g., European Migration Network 2007; Kofman 2014; Raghuram 2008). As highlighted by previous studies, characteristics such as gender, age, or country of origin affect career prospects, such as occupation level and salary (e.g., Jenkins 2004; Williams and Baláž 2008), through the social construction of the power relations underpinning the evaluation of skills (Phillips and Taylor 1980). Therefore, highly skilled migrant women offer an important context to study how the many categories of social difference (e.g., gender, migrant status and occupational sector) operate in conjunction to shape labour market participation and outcomes (Grigoleit-Richter 2017; Raghuram 2008; Shirmohammadi et al. 2018).

Most of the literature on the topic has studied the antecedents to qualification-matched employment (Shirmohammadi et al. 2018), looking, for instance, at individual-level characteristics of skilled migrant women (e.g., migratory legal status, education and language proficiency) (e.g., Aure 2013; Syed and Murray 2009), or the problems and barriers that they face (e.g., work-life balance, social integration and networking) (e.g., Pio 2005; GrigoleitRichter 2017). Relatively less attention has been paid to the initiatives in place to help them to overcome these obstacles (e.g., Iredale 2005), or to the strategies and agentic roles 
employed by women themselves (e.g., Colakoglu et al. 2018; Riaño 2011; Shih 2006), and the final outcome in terms of their engagement in the labour market and society at large.

The Special Issue on Highly Skilled Migrant Women: Achievements and Contributions in Knowledge-Based Economies stems from the international conference "Promoting highly skilled migrant women in a global knowledge economy", held at the University of Bologna in September $2019^{1}$ and organized by the authors of this Special Issue. The purpose of the conference was advancing empirical knowledge on the highly skilled migration of women in the knowledge-based economy from different disciplinary perspectives, so as to offer relevant recommendations for policy and practice. The call for papers for the academic session was subsequently (re)launched to a broader and academic audience in order to further develop theoretical knowledge on this understudied, yet constantly growing, field of research.

This Special Issue aims at addressing several research questions, from different disciplinary perspectives. The topics addressed within this collection of papers, and that we would like to draw attention to, in order to stimulate future discussion, include the following:

- The barriers and resources for the employability of highly skilled migrant women according to professional labour market intermediaries, including the training needs of professional labour market intermediaries to work more effectively with migrant women qualified in traditionally male-dominated sectors, such as Science, Technology, Engineering and Mathematics (STEM);

- The quality of employment of highly skilled native and foreign-born women and men in the labour market, the distribution of paid employment and family work between couples and their effect on highly skilled migrant women;

- The entrepreneurial intentions of highly skilled women with refugee experience;

- The impact of gender, country of origin, migratory and parental status as well as reasons for migration on the financial, career, subjective and social wellbeing experienced by highly skilled female immigrants.

The articles of this Special Issue contribute to the consolidation of the extant scientific literature by illuminating underinvestigated topics, issues and targets, such as the labour market intermediaries' perspective on the employability of highly qualified migrant women (Ricci, Crivellaro and Bolzani in this Special issue), the processes underlying deskilling and failed career advancement in the receiving country (Riaño), the perspective of the sending country on the perceived discrimination of Latvian tertiary-educated women emigrants (Šūpule), entrepreneurial intentions among highly skilled women with a refugee background (Lazarczyk-Bilal and Glinka) and the intersectional analysis of factors shaping the different dimensions of highly skilled migrants' wellbeing (Spadavecchia and Yu).

Drawing on their research results, the authors of these articles outline recommendations for policy makers ranging from ad hoc training-targeting both labour market intermediaries and highly qualified migrant women-to the implementation of gender equality policies facilitating work-life balance; the elaboration of migration policies specifically addressing the labour inclusion of highly skilled migrants from an intersectional perspective; and the simplification, across EU countries, of the procedures for the recognition of immigrants' educational and professional qualifications.

Future research should take a step forward and approach the innovation, knowledge spillovers and socio-economic wellbeing of highly qualified migrant women in receiving countries.

The contribution by Aurora Ricci, Francesca Crivellaro and Daniela Bolzani explores the labour market intermediaries' perceptions of the barriers and resources in the employability of highly skilled migrant women with a background in Science, Technology, Engineering and Mathematics (STEM), as well as their training needs to more effectively work with this highly specific category. Their study is based on the data collected through a quantitative survey covering five countries (Greece, Hungary, Italy, Sweden and the United Kingdom) and targeting professionals operating in different domains (e.g., educators, trainers, social workers, recruiters, job counsellors and career advisors). The majority of the 
survey respondents identified language proficiency as a main barrier for employability; professionals from Greece and Italy (traditionally considered as "access gates" for migrants) were, instead, more prone to acknowledging the importance of context-specific structural constraints (e.g., lack of recognition of home country qualification and discrimination by employers) in shaping women's de-skilling and exclusion in the receiving country. While labour market intermediaries across Europe perceive migrant women with a STEM background as having low employability prospects, some resources related to the individuals' psychological capital (e.g., resilience and self-efficacy) were depicted as important to facilitate women's economic inclusion.

Yvonne Riaño analyses labour market inequalities based on gender and ethnicity in Switzerland, unravelling how the intersection of these two categories of social difference contributes to unequal employment outcomes. The research methodology combined descriptive analysis of secondary data and qualitative life-course analysis. The first provided a numerical overview of the differences in the employment situation of the categories taken into consideration (native and foreign-born women and men) by analysing four indicators (employment rate, income, adequacy of paid work according to the professional qualification and employment status). The second explained the processes and dynamics underlying emerging trends by connecting career trajectories with key biographical milestones (e.g., family reunification and the birth of a child) and couples' arrangements regarding work-life balance. The study reveals how gender and ethnicity play a central role in determining a lower quality in the employment situation of foreign-born, highly skilled migrant women, who score the lowest rates of all four indicators taken into consideration in the statistical analysis. At the same time, the author highlights how traditional gender culture affects career trajectories in specific life turning points, hampering the possibility for highly qualified migrant women to use their professional skills in the Swiss labour market.

Inese Šupule addresses, from a gendered perspective, the issue of perceived discrimination in the workplace among tertiary-educated Latvian first-generation female emigrants. The author identified three items featuring perceived unfair treatment: more frequent assignment of unpleasant and/or unprofitable tasks compared to host-country nationals; pressure to take annual leave during the "off season"; lower income than host-country nationals for similar work. These dependent variables were correlated with two sets of independent variables: background characteristics, host country and workplace industry variables, on the one hand; economic and sociocultural integration (including the possibility to use the qualifications achieved in the home country), on the other. The binary logistic regression reveals that some factors increase the possibility of perceived discrimination. While age, destination country and attachment to home country do not seem to have any significant impact on perceived discrimination, working in a specific industry sector (IT and telecommunications, manufacturing and energy sectors, health and social care and the trade and catering and hospitality sectors), low attachment to the receiving country, lack of formal job contract, problems in the recognition of the qualification achieved in the home country and financial difficulties do.

Nina Lazarczyk-Bilal and Beata Glinka explore the individual-level determinants of the entrepreneurial intentions of highly skilled people with refugee experience in Sweden. Specifically, the authors focused on self-employment intentions among Syrian female refugees and asylum seekers by integrating thorough statistical analysis with two case studies. Contrary to what was expected, their study shows that highly skilled women with a refugee background are equally likely to have entrepreneurial intentions as their male counterparts, even though they were not entrepreneurs in their home countries. Some factors seem to compensate these determinants hampering inclination to self-employment and, namely, educational qualifications associated with employment-prone occupational choices as well as lack of entrepreneurial experience. These compensation factors encompass (i) a positive representation of self-employment in the Syrian culture; (ii) the existence of entrepreneurial role models in the wider family; (iii) leadership aspirations and the 
supportive role of the host country environment (e.g., availability of services allowing work-life balance; gender norms supporting women's access to the productive sphere).

Spadavecchia and Yu question the widespread assumption in migration studies that polarizes discrimination vs. privilege by demonstrating, from an intersectional perspective, how the same subject can experience both, depending on their own intersected identities. Authors show that privilege is a situational and relational concept: being highly skilled does not necessarily translate into empowerment and emancipation for migrant women. Their qualitative exploratory study highlights how gender works as the main moderator of experienced well-being in different domains (career, financial, subjective and social wellbeing). Compared to other categories, highly qualified women who migrate to reunite with their partners experience the lowest levels of career well-being, especially when they are mothers and have an extra-European background. All in all, when gender (being a woman), migratory status, county of origin (being extra-European national), motherhood and migration reasons (access to the receiving country through family reunification visa) intersect, the level of experienced well-being decreases, while perceived discrimination increases.

We hope that this Special Issue will gain attention and stimulate reflection on the topic of highly skilled migrant women in knowledge-based economies. We all need a better understanding of the phenomenon, in order to remove barriers, to create conditions for their integration and contribution to the economic, social and technological enhancement of our countries.

Conflicts of Interest: The authors declare no conflict of interest.

\section{Note}

1 The conference (Bologna, 12th-13th of September 2019) was organized as the final dissemination event of the Erasmus+ project "EUMentorSTEM. Creation of a EUropean e-platform of MENTORing and coaching for promoting migrant women in Science, Technology, Engineering and Mathematics" (2017-1-IT02-KA204-036520) coordinated by the University of Bologna (2017-2019).

\section{References}

Al Ariss, Akram, Iris Koall, Mustafa Özbilgin, and Vesa Suutari. 2012. Careers of skilled migrants: Towards a theoretical and methodological expansion. Journal of Management Development 31: 92-101. [CrossRef]

Aure, Marit. 2013. Highly skilled dependent migrants entering the labour market: Gender and place in skill transfer. Geoforum 45: 275-84. [CrossRef]

Burmann, Martina, Maria Hofbauer Perez, Vanessa Hoffmann, Carla Rhode, and Sebastian Schworm. 2018. Highly Skilled Labour Migration in Europe. ifo DICE Report 16: 42-52.

Colakoglu, Saba, Dilek G. Yunlu, and Gamze Arman. 2018. High-skilled female immigrants: Career strategies and experiences. Journal of Global Mobility: The Home of Expatriate Management Research 6: 258-84. [CrossRef]

Dietz, Joerg, Chetan Joshi, Victoria M. Esses, Leah K. Hamilton, and Fabrice Gabarrot. 2015. The skill paradox: Explaining and reducing employment discrimination against skilled migrants. International Journal of Human Resource Management 26: 1318-34. [CrossRef]

Enríquez, Carmen González, and Anna Triandafyllidou. 2016. Female High-Skilled Emigration from Southern Europe and Ireland after the Crisis. In High-Skill Migration and Recession. Edited by Anna Triandafyllidou and Irina Isaakyan. London: Palgrave Macmillan, pp. 44-68.

European Migration Network. 2007. Conditions of Entry and Residence of Third Country Highly-Skilled Workers in the EU: EMN Synthesis Report. Available online: http:/ / emn.ie/files/p_20100716103748Conditions\%20of\%20entry\%20synthesis\%20report.pdf (accessed on 6 April 2021).

Eurostat. 2011. Migrants in Europe. A Statistical Portrait of the First and Second Generation. Available online: https://ec. europa.eu/eurostat/documents/3217494/5727749/KS-31-10-539-EN.PDF/bcf27a60-7016-4fec-98c5-e8488491ebbd (accessed on 6 April 2021).

Grigoleit-Richter, Grit. 2017. Highly skilled and highly mobile? Examining gendered and ethnicised labour market conditions for migrant women in STEM professions in Germany. Journal of Ethnic and Migration Studies 43: 2738-55. [CrossRef]

Iredale, Robyn. 2005. Gender, immigration policies and accreditation: Valuing the skills of professional women migrants. Geoforum 36: 155-66. [CrossRef]

Jenkins, Sarah. 2004. Gender, Place and the Labour Market. Aldershot: Ashgate.

Kofman, Eleonore. 2014. Towards a gendered evaluation of (highly) skilled immigration policies in Europe. International Migration 52: 116-28. [CrossRef]

Lo, Lucia, Wei Li, and Wan Yu. 2017. Highly-skilled Migration from China and India to Canada and the United States. International Migration 57: 1-17. [CrossRef] 
OECD. 2016. Migration Policy Debates. Available online: http:/ /www.oecd.org/migration/migration-policy-debates.htm (accessed on 6 April 2021).

OECD-EU. 2016. Recruiting Immigrant Workers: Europe 2016. Paris: OECD Publishing.

Özden, Çağlar, Christopher R. Parsons, Maurice Schiff, and Terrie L. Walmsley. 2011. Where on earth is everybody? The evolution of global bilateral migration 1960-2000. The World Bank Economic Review 25: 12-56. [CrossRef]

Phillips, Anne, and Barbara Taylor. 1980. Sex and skills. Notes towards a feminist economics. Feminist Review 6: 79-88. [CrossRef]

Pio, Edwina. 2005. Knotted strands: Working lives of Indian women migrants in New Zealand. Human Relations 58: 1277-99. [CrossRef]

Raghuram, Parvati. 2008. Migrant women in male-dominated sectors of the labour market: A research agenda. Population, Space and Place 14: 43-57. [CrossRef]

Riaño, Yvonne. 2011. Drawing new boundaries of participation: Experiences and strategies of economic citizenship among skilled migrant women in Switzerland. Environment and Planning A 43: 1530-46. [CrossRef]

Shih, Johanna. 2006. Circumventing discrimination: Gender and ethnic strategies in Silicon Valley. Gender E Society 20: 177-206.

Shirmohammadi, Melika, Mina Beigi, and Jim Stewart. 2018. Understanding skilled migrants' employment in the host country: A multidisciplinary review and a conceptual model. The International Journal of Human Resource Management 30: 96-121. [CrossRef]

Syed, Jawad, and Peter Murray. 2009. Combating the English language deficit: The labour market experiences of migrant women in Australia. Human Resource Management Journal 19: 413-32. [CrossRef]

Syed, Jawad. 2008. Employment prospects for skilled migrants: A relational perspective. Human Resource Management Review 18: 28-45. [CrossRef]

Triandafyllidou, Anna, and Irina Isaakyan. 2014. EU Management of High Skill Migration. Available online: https://cadmus.eui.eu/ bitstream/handle/1814/34706/RSCAS_GGP_2014_04_PolicyBrief.pdf?sequence=1\%2526isAllowed=y (accessed on 6 April 2021).

UNDESA. 2020. International Migration 2020. Highlights. New York: United Nations Department of Economic and Social Affairs, Population Division (ST/ESA/SER.A/452).

Williams, Allan, and Vladimír Baláž. 2008. International Migration and Knowledge. London: Routledge. 